\title{
THE COST OF TREATING NEONATES IN INTENSIVE CARE UNIT IN A TERTIARY LEVEL TEACHING HOSPITAL
}

\author{
Sahisnuta Basnet, ${ }^{1}$ Suraj Adhikari, ${ }^{2}$ Mukunda Timilsina ${ }^{1}$
}

${ }^{1}$ Department of Pediatrics, ${ }^{2}$ Manipal College of Medical Sciences, Pokhara, Nepal

\begin{abstract}
Neonatal intensive care is associated with high costs world-wide and remains a matter of financial stress for families. This is an issue of great importance in a developing country like ours as financial burden may have a negative impact in the overall outcome of a newborn. The objective of this study was to evaluate the direct cost of treating newborns by family members in a neonatal intensive care unit (NICU). This was a prospective cross sectional study carried out in the NICU of Manipal Teaching Hospital, Pokhara, Nepal. There were 96 neonates included in this study over a period of 3 months from September to November 2020. The average cost per neonate per day was NRs. 5858 (USD 50). The highest health expenditure was incurred in neonates of gestational age of 32 to less than 37 weeks, and it was also significantly higher in neonates having birth weights less than $1.5 \mathrm{~kg}$. Preterms with hyaline membrane disease, followed by newborns with meconium aspiration syndrome resulted in maximum health costs. Maximum expenditure of the total bill was due to the cost of the bed charges. The median length of stay in the study was 5 days and the length of stay was directly and significantly related to the treatment costs.
\end{abstract}

\section{KEYWORDS}

Cost evaluation, health expenditure, Nepal, newborn

Received on: May 06, 2021

Accepted for publication: August 05, 2021

\section{CORRESPONDING AUTHOR}

Dr. Sahisnuta Basnet,

Associate Professor

Department of Pediatrics,

Manipal College of Medical Sciences,

Pokhara, Nepal

Email: sahisb@hotmail.com

Orcid No: https://orcid.org/0000-0002-2342-4944

DOI: https://doi.org/10.3126/nmcj.v23i3.40382 


\section{INTRODUCTION}

Neonatal intensive care units are among the most expensive units in a hospital as it consumes a lot of resources and its use is increasing. ${ }^{1-4}$ With consideration to economic inflations especially in a country like Nepal, where health care is self-paid, the cost evaluation is particularly important. Also, every clinician who is involved in critical care should actively be involved in understanding the costs in their unit, how the cost relates to therapeutics and clinical outcome. ${ }^{4}$

Data reveals that $6 \%$ of total household expenditure is on health care expenses. ${ }^{4}$ For those living below the poverty line, this accounts for more than 15\% of total household expenses. ${ }^{5,6}$

In this time of increasing healthcare costs, the role of economic evaluation of health care has become increasingly noteworthy. ${ }^{2}$ However, there is limited data regarding this information incurred by family members in Nepal. This information gathered would be useful for setting up new neonatal units in the future, for preparing families and health care worker at the time of neonatal admissions and also to explore the means of using the limited budgets families may have, more effectively.

The aim of this study was to calculate the actual expenses incurred by a family for the treatment of their infant in a neonatal intensive care unit (NICU).

\section{MATERIALS AND METHODS}

This was a hospital based prospective cross sectional descriptive study carried out in the NICU of Manipal Teaching Hospital (MTH), Pokhara, Nepal. All sick neonates who were admitted during one financial quarter (3 months) from September to November 2020 were eligible for the study provided they completed at least 24 hours of stay in NICU. For this study, NICU was defined as a separate physical unit specially designated for treatment of all neonates requiring comprehensive treatment, observation and care including phototherapy.

Clinical data including neonatal demographics, reason for NICU admission, total days of hospital stay and neonatal outcome were collected on a structured proforma by a trained doctor on duty. Financial statements obtained from the department of finance and accounts of MTH and from the patient party (for those expenses which were not included in the financial statement obtained from the hospital). Financial statement included hospital bed charges, charges for any procedures performed on the baby, imaging charges, drug charges and charges for other consumables such as diapers, wipes, creams/lotions. All charges during the entire length of stay were documented. The cost was calculated per patient and per patient day in NICU. Charges were expressed in Nepali rupees (NPR) and converted to US dollars (USD) in accordance with the exchange rate at the time of writing the paper ( 1 USD $=118$ NPR).

The data was analyzed using SPSS version 18. Descriptive statistics were used for baseline characteristics and cost information for each patient. Values were expressed in terms on mean, SD, median with IQR, frequencies and percentages. Associations between variables were analyzed using chi-squared test or student's t-test wherever appropriate and p-value $<0.05$ was regarded as statistically significant. Ethical approval for this study was taken from Institutional Review Committer of Manipal College of Medical Sciences.

\section{RESULTS}

A total of ninety six neonates were included in the study. Among them, $61 \%$ were males with median gestational age of 38.5 weeks and median age of 2 days. More than 30\% were prematurely born. The median hospital stay was 5 days, with neonatal sepsis being the most common diagnosis. The median family income was NRs. 26,500 (USD 225). The mean cost of care was NRs. 5858 (USD 50) per patient per day with a range of NRs. 1878-27584 (USD 16-234). The characteristics of study population are presented in Table 1 . The health expenditure was the highest in neonates of gestational age of 32 to less than 37 weeks followed by less than 32 weeks. It was also significantly higher in neonates of birth weight less than $1.5 \mathrm{~kg}$ and hospital admission of more than 15 days. Preterm with hyaline membrane disease resulted in maximum health costs followed by meconium aspiration syndrome. Table 2 shows median cost during hospital stay based on various parameters. More than $50 \%$ of total costs were due to hospital bills in gestational age of more than 32 weeks but the maximum costs incurred in less than 32 weeks gestation were due to drugs other than antibiotics. Irrespective of birth weight, duration of hospital stay or diagnosis, maximum expenditure was due to bed charges in all categories. Table 3 shows the cost distribution under various categories 
Table 1: Characteristics of neonates

\begin{tabular}{|c|c|}
\hline Characteristics & N (\%) \\
\hline Age in days [Median (IQR)] & $2(1-5.75)$ \\
\hline $\begin{array}{l}\text { Gender } \\
\text { Male } \\
\text { Female }\end{array}$ & $\begin{array}{l}59(61.5) \\
37(38.5)\end{array}$ \\
\hline $\begin{array}{l}\text { Gestational Age in weeks [Median (IQR)] } \\
<32 \text { weeks } \\
32-<37 \text { weeks } \\
\geq 37 \text { weeks }\end{array}$ & $\begin{array}{c}38.50(36-40) \\
4(4.2) \\
26(27.1) \\
66(68.8)\end{array}$ \\
\hline $\begin{array}{l}\text { Birth Weight in kg [Median (IQR)] } \\
<1.5 \mathrm{~kg} \\
1.5-<2.5 \mathrm{~kg} \\
\geq 2.5 \mathrm{~kg}\end{array}$ & $\begin{array}{c}2.72(2.13-3.39) \\
6(6.3) \\
24(25.0) \\
66(68.8)\end{array}$ \\
\hline $\begin{array}{l}\text { Type of Delivery } \\
\text { Vaginal } \\
\text { Instrumental } \\
\text { Cesarean Section }\end{array}$ & $\begin{aligned} 48 & (50.0) \\
4 & (4.2) \\
44 & (45.8)\end{aligned}$ \\
\hline $\begin{array}{l}\text { Singleton Pregnancy } \\
\text { Twins }\end{array}$ & $\begin{array}{c}94(97.9) \\
2(2.1)\end{array}$ \\
\hline $\begin{array}{l}\text { Inborn } \\
\text { Outborn }\end{array}$ & $\begin{array}{l}62(64.6) \\
34(35.4)\end{array}$ \\
\hline $\begin{array}{l}\text { Diagnosis } \\
\text { Neonatal sepsis } \\
\text { Preterm with hyaline membrane disease } \\
\text { Meconium aspiration syndrome } \\
\text { Neonatal Hyperbilirubinemia } \\
\text { Low birth weight } \\
\text { Transient tachypnea of newborn } \\
\text { Pneumonia } \\
\text { Neonatal depression } \\
\text { Perinatal asphyxia } \\
\text { Others }\end{array}$ & $\begin{array}{c}27(28.1) \\
13(13.5) \\
13(13.5) \\
11(11.5) \\
8(8.3) \\
6(6.3) \\
5(5.2) \\
4(4.2) \\
2(2.1) \\
7(7.29)\end{array}$ \\
\hline $\begin{array}{l}\text { Days of Hospital admission [Median (IQR)] } \\
\text { Upto } 5 \text { days } \\
6 \text { - } 10 \text { days } \\
\text { 11- } 15 \text { days } \\
>15 \text { days }\end{array}$ & $\begin{aligned} 5 & (3-8) \\
60 & (62.5) \\
22 & (22.9) \\
10 & (10.4) \\
4 & (4.2)\end{aligned}$ \\
\hline $\begin{array}{l}\text { Outcome } \\
\text { Discharged } \\
\text { Leave against Medical advice } \\
\text { Referred } \\
\text { Death }\end{array}$ & $\begin{aligned} 79 & (82.3) \\
10 & (10.4) \\
1 & (1.0) \\
6 & (6.3)\end{aligned}$ \\
\hline Monthly Family Income [Median (IQR)] & USD 225[NRs. $26,500(20,000-35,000)]$ \\
\hline
\end{tabular}


Table 2: Average cost during hospital stay

\begin{tabular}{|c|c|c|}
\hline Characteristics & Total costs, Median (IQR) & $\mathrm{p}$ - value \\
\hline $\begin{array}{l}\text { Gestational age } \\
<32 \text { weeks } \\
32-<37 \text { weeks } \\
\geq 37 \text { weeks }\end{array}$ & $\begin{array}{l}\text { USD } 297 \text { [NRs.35,084 }(65,196)] \\
\text { USD } 379 \text { [NRs.44,717 }(49,584)] \\
\text { USD } 180 \text { [NRs.21,255 }(16,064)]\end{array}$ & $<0.001$ \\
\hline $\begin{array}{l}\text { Birth Weight in kg } \\
<1.5 \mathrm{~kg} \\
1.5-<2.5 \mathrm{~kg} \\
\geq 2.5 \mathrm{~kg}\end{array}$ & $\begin{array}{l}\text { USD } 382 \text { [NRs.45,026 }(64,433)] \\
\text { USD } 312 \text { [NRs.36,827 }(48,096)] \\
\text { USD } 195 \text { [NRs.23,014 }(17,043)]\end{array}$ & 0.001 \\
\hline $\begin{array}{l}\text { Gender } \\
\text { Male } \\
\text { Female }\end{array}$ & $\begin{array}{l}\text { USD } 218 \text { [NRs.25,670 }(25,361)] \\
\text { USD } 255 \text { [NRs.30,094 }(35,245)]\end{array}$ & 0.93 \\
\hline $\begin{array}{l}\text { Diagnosis } \\
\text { Neonatal sepsis } \\
\text { Preterm with hyaline membrane disease } \\
\text { Meconium aspiration syndrome } \\
\text { Neonatal Hyperbilirubinemia } \\
\text { Low birth weight } \\
\text { Transient tachypnea of newborn } \\
\text { Pneumonia } \\
\text { Neonatal depression } \\
\text { Perinatal asphyxia } \\
\text { Others }\end{array}$ & $\begin{array}{l}\text { USD } 146 \text { [NRs.17,213 (9,014)] } \\
\text { USD } 442 \text { [NRs.52,118 }(58,380)] \\
\text { USD } 390 \text { [NRs.46,075 }(35,851)] \\
\text { USD } 95 \text { [NRs.11,265 }(5,544)] \\
\text { USD } 359 \text { [NRs.42,398 }(41,439)] \\
\text { USD } 261 \text { [NRs. 30,756 }(25,962)] \\
\text { USD } 247 \text { [NRs.29,203 (23,429)] } \\
\text { USD } 122 \text { [NRs.14,450 (7,403)] } \\
\text { USD 158 [NRs.18,633] } \\
\text { USD } 221 \text { [NRs. 26,085 (20,517)]] }\end{array}$ & $<0.001$ \\
\hline $\begin{array}{l}\text { Days of Hospital admission } \\
\text { Upto } 5 \text { days } \\
6 \text { - } 10 \text { days } \\
11-15 \text { days } \\
>15 \text { days }\end{array}$ & $\begin{array}{l}\text { USD } 169 \text { [NRs.19,885 (11,768)] } \\
\text { USD } 361 \text { [NRs.42,579 (22,146)] } \\
\text { USD } 662 \text { [NRs.78,107 (33,596)] } \\
\text { USD } 779 \text { [NRs.91,922 }(49,375)]\end{array}$ & $<0.001$ \\
\hline
\end{tabular}

on the basis of gestational age, birth weight, duration of hospital stay and diagnosis.

\section{DISCUSSION}

To the best of the authors' knowledge, this study is the first to focus on the NICU costs in a tertiary level teaching hospital in our country. NICU admissions are expensive and several studies done both in developing and developed countries have shown this to be true., ${ }^{2,7,8}$ It was recorded in our study that the average cost of treatment per day per newborn admitted in NICU was NRs.5857.68 (USD 50). When compared with the per capita income of Nepal of USD 1071.1 and also the median monthly family income (NRs. 26,500), this expenditure stands out as a substantial amount for an average family to incur. ${ }^{9}$

In the present study, it was seen that $61.5 \%$ of the admitted neonates were males. Majority (61\%) of the admissions being males were also seen in similar studies by Sharma et $a l^{8}$ and Geitiona et al. ${ }^{10}$ Male predominance in admissions could be related to the strong patriarchal traditions in these societies where men are given more importance than females.

The overall average medical cost for the treatment of low birth weight neonates recorded in this study was NRs. 42,398 (USD 
Table 3: Cost distribution (Values indicate percentage of total under each category)

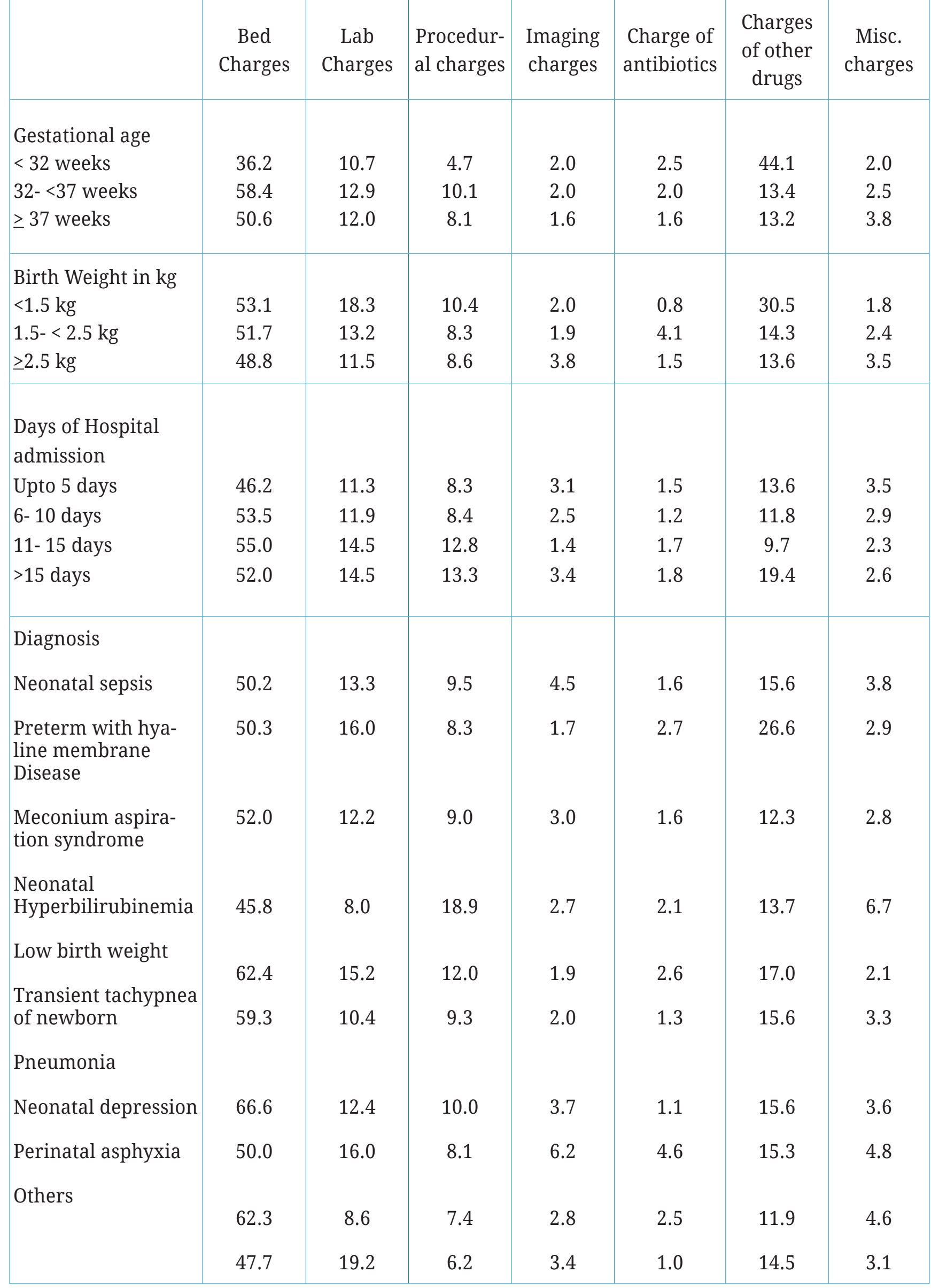


359). This is comparative to the cost seen in a similar analysis in Nigeria. ${ }^{11}$ However, a study in Iran showed that their average cost of treating similar cases was more than 10 times than that seen in our study. ${ }^{12}$ This vast difference can be attributed to different years and geographical area with different inflation rates and charging of consumables, drugs may differ among NICUs. Also, the Iranian study had included personnel salary in their study, which would bring up the costs considerably.

The mean duration of stay noted in our study population was 5 days. This was in cohort with reports from studies by Sharma et al ${ }^{10}$ and Karambelkar et al. ${ }^{13}$ Like in other reports we found that length of stay in our NICU was directly proportional to the cost of NICU. ${ }^{13,14}$ There are studies that reported, those having less days of stay but critically ill, also incurred considerably large bills whereas our study observed the opposite. ${ }^{12,15}$ Our explanation for this is that those with critical illness either died before they could procure large bills or left on LAMA due to the poor prognosis.

The most frequent diagnosis needing NICU care in our study was neonatal sepsis (28.1\%). Other similar studies done in this part of the world showed that sepsis was also the major cause of admission in their NICU.1,5,10,13 In the present study it was seen that the highest expenses were procured for preterm neonates having hyaline membrane disease (HMD). HMD requires surfactant therapy as one of the main modalities of its management and surfactant is expensive and evidently accounted for a major share in contributing to the total bill in our study. This condition also requires longer duration of admission and repeated investigations which may predispose to hospital acquired infections which further potentiate the already high hospital expenses. However, Karambelkar et $a l^{11}$ and Ekwochi et $a^{13}$ found necrotizing enterocolitis to be the most expensive condition in terms of cost required for management.

The least costly diagnosis seen in the present study was neonatal hyperbilirubinemia. This finding was similar to that seen in another studies. ${ }^{13}$ Treatment of neonatal hyperbilirubinemia requires lesser admission days, drugs and procedures and as length of stay strongly correlates with total hospital expenses, it would seem reasonable to state that this condition would be lesser expensive to treat.
It is difficult to generalize economic burdens across different countries or even across hospitals in the same country as they are influenced by various factors such as pricing policies of different hospitals, methods used to obtain the bills, local ethics and even social diversity. ${ }^{3}$ We suggest that similar studies should be carried out in different neonatal units of Nepal so that comparable data can be obtained and this be utilized for proper assessment of cost evaluation. Furthermore, this will help in evaluating cost effective patient outcomes and judicious resource allocations.

Our study had several significant strengths; the sample size was adequate with a good distribution of various diagnoses. We were able to capture accurate data as the billings were acquired from the financial department of the hospital, based on actual receipts and didn't have to rely on patient party's recall of various expenses.

The limitations of our study included: this study reflects the NICU cost of a private teaching hospital and findings cannot be generalized. It was a time limited, single centered study and the costs were not assessed in terms of severity of illness. Another limitation was that the authors didn't calculate indirect costs (travel expenses, food and lodging expenses, loss of wages) of the care-givers for managing their sick newborns. If they were calculated, it would further make the cost of care in NICU higher.

In conclusion, the direct cost of NICU admissions is high. The expenditures were highest in preterm babies having hyaline membrane disease. Maximum expenditure of the total bill was due to bed charges. It was also noted that length of stay was directly and significantly related to the treatment costs.

Neonatal health costs is an issue of extreme importance in a developing country like ours since financial burden may adversely affect the overall outcome of a new born and affect our neonatal mortality rate.

\section{ACKNOWLEDGMENTS}

The authors would like to thank the Department of Finance and Accounts, MTH, Pokhara, all the participants and the hospital staff for all their support in acquiring the data.

Conflict of interest: None

Source of research fund: None 


\section{REFERENCES}

1. Anwar Z, Butt TK. Cost of Patient Care in Neonatal Unit. Pak Paed J 2009; 33: 14-8. researchgate.net/ publication/288632544_Cost_of_patient_care_in_ neonatal_unit

2. Narang A, Kiran PSS, Kumar P. Cost of Neonatal Intensive Care in a Tertiary Care Center. Indian J Pediatr 2005; 42: 989-97. pubmed.ncbi.nlm.nih. gov/16269829/

3. Rogowski J. Measuring the cost of neonatal and perinatal care. Pediatr 1999; 103(Suppl): 329-35. pubmed.ncbi.nlm.nih.gov/9917475/

4. Jayaram R, Ramakrishnan N. Cost of intensive care in India. Indian J Crit Care Med 2008; 12: 5561. ncbi.nlm.nih.gov/pmc/articles/PMC2738307/

5. Sunny AK, Gurung R, Gurung A, Basnet O, KC A. Out of pocket expenditure for sick newborn care in referral hospitals of Nepal. Maternal Child Health J 2020; 24(Suppl 1): S57-65 pubmed.ncbi. nlm.nih.gov/31981065/

6. Saito E, Gilmour S, Rahman M, Gautam GS, Shrestha PK, Shibuya K. Catastrophic household expenditure on health in Nepal: A cross-sectional survey. Bull World Health Organ 2014; 92: 760-7. ncbi.nlm.nih.gov/pmc/articles/PMC4208475/

7. Cheah IG, Soosai AP, Wong SL, Lim TO. CostEffectiveness Analysis of Malaysian Neonatal Intensive Care Units. J Perinatol 2005; 25: 47-53. nature.com/articles/7211196

8. Geitona M, Hatzikou M, Hatzistamatiou Z, Anatasiadou A, Theodoratou TD. The economic burden of treating neonates in Intensive Care Units (ICUs) in Greece. Cost Eff Resour Alloc 2007; 5:9. doi.org/10.1186/1478-7547-5-9
9. The Word Bank. GDP per capita.World bank national accounts data, and OECD National Accounts data files. [home page on the internet]. No date [cited 2021 May 1]. Available from: data.worldbank.org/indicator/NY.GDP.PCAP. CD?locations $=\mathrm{NP}$

10. Sharma S, Chapagain RH, Pathak OK et al. The economic burden of neonatal intensive care unit admission at a community hospital of central Nepal. J Nepal Pediatr Soc 2020; 40: 42-7 nepjol. info/index.php/JNPS/article/view/28600

11. Ekwochi U, Osurorah DC, Ndu IK et al. Out of pocket cost of managing sick newborns in Enugu, southeast Nigeria. Clinicoecon Outcomes Res 2014; 6: 29-35. ncbi.nlm.nih.gov/pmc/articles/ PMC3896288/

12. Cömert S, Ağzıkuru T, Akin Y et al. The Cost Analysis of Preterm Infants from a NICU of a State Hospital in Istanbul. Iran J Pediatr 2012; 22: 185-90. PMID: 23056884; PMCID: PMC3446073.

13. Karambelkar G, Malwade S, Karambelkar R. Cost-analysis of healthcare in a private-sector neonatal intensive care unit in India. Indian Pediatr 2016; 53: 793-5. doi.org/10.1007/s13312016-0933-X

14. Haque A, Siddiqui NR, Kumar R, Hoda M, Lakahni G, Hooda K. Cost of care in a paediatric intensive care unit of a tertiary-care university hospital of Pakistan. J Pakistan Med Assoc 2015; 65: 651-4. ecommons.aku.edu/pakistan_fhs_mc_ med_intern_med/113/ 